\section{Education, Pharaonic Egypt}

KATHARINA ZINN

Unlike modern societies, in ancient Egypt the child's world was not separated from that of the adult. Once having survived infant mortality and well before the commencement of maturity, children increasingly adopted adult behavior, maybe even from as early as age five onwards (Strouhal and Forman 1992: 28): obtaining practical skills took the place of playing and sporting, and knowledge was gained from mimicking parents or other adult relatives. Education comprised general upbringing and training for a particular profession. On the other hand, education in writing and reading could overcome social barriers and was prerequisite for ancient Egyptians entering into a high ranking profession. It is interesting to note that there were no class restrictions on who could be educated as a scribe (Szpakowska 2008: 104). Educated people could rise socially, as seen with AMENHOTEP, SON OF HAPU, serving under Amenhotep III. He came from the Delta, born into a low ranking family and became the king's favorite (Janssen 2007: 57).

At home boys learned mainly from their fathers, girls from their mothers. It is thought they taught the children the basics of MAAT, including the right behavior within their environment, religious belief, rites, and performance, as well as ethical principles. After about the age of five, boys and girls were separated in their learning experiences, in the sense that girls often stayed with their mothers. In tomb scenes, they are often shown playing separately, as in the Saqqara tomb of Mereruka from the 6th Dynasty (chamber A13, east wall). In scenes of daily life, girls are usually shown with their mothers rather than their fathers, while the sons are depicted standing next to their fathers. Boys from the elite became "schoolboys" and received a formal education (Janssen 2007: 60).
There was no formal school system for all children, so the majority of people stayed illiterate. Peasant children probably never had a proper education. It is likely they received basic education and vocational training - all that they needed to know for being farmers staying within their family (Feucht 1995: 307-36). This knowledge was handed down from generation to generation. Boys from poor families began helping with the men's jobs in the occupation their father held, often seen as an apprenticeship. This was called a father-son-relationship, but also could be taken on by non-blood-related boys. However, male children of higher classes and from scribal families started early with their school career.

A boy's education started between the ages of five and ten and lasted until he was between twelve and sixteen, which would also have been the time of circumcision as transition to adulthood (Janssen 2007: 60-79; Strouhal and Forman 1992: 35). At this time they were considered adults and could begin to work for themselves. This would be the earliest age for men to marry, but normally they were between sixteen and twenty years of age when they took their first wife (Strouhal and Forman 1992: 51-2; Brewer and Teeter 2007: 110). Education took a large amount of the average life span.

Girl's lives were different, more centered on the home and family. At an early age, girls would begin to learn from their mothers how to keep house and maintain the fields, to sew, and to prepare food (Janssen 2007: 42; Feucht 1995: 315, 336-9), which took more time than the educational hours of boys. Girls were expected to marry after they began menstruating around the age of twelve or thirteen, as indicated in Ptolemaic marriage contracts, although there is evidence of girls marrying earlier (Feucht 1995: 32-3; Strouhal and Forman 1992: 51-2; Brewer and Teeter 2007: 110). The famous scribe Qenherkhepeshef of DEIR EL-MEDINA married the twelve-year-old girl Nanakht when he was fifty-four (Strouhal 
and Forman 1992: 51). Taimhotep mentioned on her private funerary stela (British Museum EA147), from the late Ptolemaic period, that she married the high priest of Ptah in Memphis when she was still thirteen and gave birth to four children within the next thirteen years, before she died four years later, aged thirty (Lichtheim 1980: 59-65). Most newlywed women had a child within the first year of marriage, as mentioned in the demotic story of Setne Khamwas and Naneferkaptah (Setne I, Lichtheim 1980: 128). The school texts refer to students being boys, as stated in the Teaching of Khety mentioned below and P. Anastasi III 3/13, as well as in The Instruction of Any, where it is said, that "he understands little when he recites the words in the books" (Lichtheim 1976: 144). However, texts never particularly refer to girls, suggesting other environments for teaching them. The rare exception is Pap. Leiden I370, a late Ramesside letter, where within the usual encouragement to study hard, a daughter of a Khonsu-mes is mentioned. It is also said that she actively shall produce a letter to a superior scribe (Toivari-Viitala 2001: 189). Girls from higher rank or elite families normally received training in singing, dancing, and musical instruments (Strouhal and Forman 1992: 35).

Pap. Anastasi III (3, 7-8) mentions a school for (probably female) singers at Memphis. From the 6th Dynasty we know of Rawer, being a "teacher (seba) of the royal singers" (Giza, Central Field, Porter and Moss 1974: 265; Manniche 1991: 122). We can find reliefs in tombs of musicians and dancers, showing them with their female students (Brunner 1957: 47-9). The best known is in the Middle Kingdom tomb of the "instructor (sekhedj) of singers" Khesuwer at Kom el-Hisn, showing him giving lessons in sistrum playing and hand clapping (Manniche 1991: 123). These girls could have careers as musicians, but also take part in other musical employment such as "overseer (imi-ra) of female singers," as we know from a woman called Hemetre. She seemed to have been a high ranking woman at the end of the 5th or the 6th Dynasty, as she was able to usurp her tomb Saqqara No. 6 (C 15) from a man named Ty who was wab-priest of Re in the sun temple of Sahure, the second ruler of the 5th Dynasty (Porter and Moss 1978: 450). Furthermore, scenes showing girls or young professional performers dancing or doing acrobatics, such as those seen on the Red Chapel of Hatshepsut in Karnak, are connected with religion, cult, and ritual and therefore suggest that these elaborate skills were learnt gradually. They are known as female dancers (khebyt). Professional titles as female musicians of a god/goddess (shemayt or khenwt of mostly Amun or Hathor) also imply some method of education, so that they could follow the required ritual. Women possessing these titles owned their individual statues, such as the one belonging to Meryt, the wife of Maya, treasurer of Tutankhamun (18th Dynasty), found in Saqqara (tomb LS 27). She is shown clasping a menat (RMO Leiden AST.2). Since the Old Kingdom, female dancers belonged to groups of male and female musicians delivering funerary endowments, who acted for the deceased in front of his tomb chapel. This is made clear from an inscription (jba jn khener en per-djet, dancing by the group of musicians of the house of eternity; i.e., tomb or the endowment for the tomb) in the tomb of Neb-Kaw-Khor in Sakkara from the 6th Dynasty. Acting performances during funerary rites appear to imply membership of a profession.

Swimming may also have been taught to girls. Again, the texts and reliefs only speak of male students, as we also know from Min (TT109), the mayor of Tjeny (Thinis), who was Overseer of the prophets of Onuris and tutor of Amenhotep II, to whom he taught archery. Another document, the Autobiography of Kheti, prince of Siut, speaks of receiving swimming lessons (nebj) together with the royal children (Decker 1975: 22-3). However, looking at the many spoons with young female swimmers as handles, we can assume that girls were taught swimming as well, even if we take into consideration that these spoons had a 
primary fertility aspect. The motif of the swimming girl also appears on other objects (Decker 1992: 91-5).

The fact that girls were taught reading and writing in some way is shown by female literacy; they were possibly taught by family members such as fathers or older brothers. Even though we know of literate woman, such as female scribes in the entourage of a queen of the 13th Dynasty or a female official employed by the god's wife of the 26th Dynasty (Brunner 1957: 46), we have no evidence for the schooling of girls. In lower ranking families, they seem to have had tuition from - maybe female - family members, in elite families also by special tutors. One prominent example of a royal tutor was Senenmut for princess Nefrure, the daughter of Hatshepsut, who was very likely appointed by Nefrure's father Thutmose II. The title Royal Tutor (mena neswt) only appears in the 18th Dynasty. Little is known about this office. We only have images depicting the tutors with children, who are sometimes boys, where in one case he is shown teaching archery, and sometimes girls. The tutors seem to have acted as guardians before teaching the children themselves, either in physical skills or intellectual ones or overseeing their education (Roehrig 2005: 112).

Relatively easy access to the career path of a scribe and the prospect of a high status position at the end of such a career made this profession very attractive to boys and their parents. In the Teaching of Khety - a so-called instruction text compiled in the 12th Dynasty, also called Satire on the trades - being a scribe is seen as being superior to all other professions (Foster 1999). Even though it is mentioned at the beginning of this instruction that the author sent his son to a central "writing school" as a location for formal education, we know only a little about the route and practice of such education and becoming a scribe.

Unfortunately, we have no fully reliable information about the sites where schools might have been located or how schools were organized before the Middle Kingdom. During the Old Kingdom, students were trained by their fathers or officials in the houses of the latter and took part in a "father-son-relationship" (Janssen 2007: 59), even though there was some organized teaching in the family residence, as the Old Kingdom title "Chief teacher of royal children" suggests. We also have references to palace schools from the First Intermediate period and the New Kingdom (Williams 1972: 215-6). The word for school (lit.: house of instructions - at-seba or seba) is attested since the 10th Dynasty. At the beginning of the Middle Kingdom, the administration was reorganized and new bureaucracies were formed, which brought about the need for the training of more scribes with the ability to read and write to record transactions, royal events, and new policies. The Middle Kingdom, with its new and extended bureaucracy, needed more capable administrators. This might be one reason for the creation of formal education outside the family. Schools seemed to be attached to administrative units, palaces, or temples. Due to obvious orthographic differences in the Asyut Coffin Text spells and the local type of coffin decoration as well as a specific style of calcite statuettes, we can assume the existence of a writing school during the Middle Kingdom, as well as an art school during the First Intermediate period and the Middle Kingdom in Asyut, which produced high-quality texts and art work. Furthermore, more than one hundred and forty graffiti in tomb N13.1 give evidence of school teaching during the New Kingdom, mainly the 18th Dynasty. Teachers and students seem to have made excursions to this tomb, quoting literary texts and drawings on the walls. Ostraca found in tomb 3 are also connected with scribal or artistic exercises (Kahl 2007: 15, 152-4). During the New Kingdom, we also have special evidence from the Ramesseum (mortuary temple of RAMESES II in THEBESWEST), where there are plenty of inscribed ostraca as well as small offices and storage rooms, but where no clearly identifiable class rooms were found (Janssen 2007: 65), and the Temple of Mut, just outside the Karnak 
precinct. Nevertheless, we know that education in schools was focused on scribal training, as this was fundamental for administration, economic organization, and the priesthood. There is no school that we know of in Lahun, and the school of Deir El-Medina seems to have been located outside the village. The students went here on their days off (McDowell 1996: 602; contrary to Brunner 1957: 19, who suggests the school was located in town). Even though we do not know exactly where the school was situated, we know of its existence from ostraca such as O DeM 438, a so-called "Call to lessons," where the instructing scribe informs his pupil about the next assignment and the student promises to do it. Such facts as school age, class numbers, and curriculum are only known from the New Kingdom onwards (Janssen 2007: 60).

One papyrus from Lahun (Petrie Museum London, UC32196) contains model letters, some with red corrections, suggesting students and teachers at work. Similar examples can be found on various ostraca all over the country. There is more evidence from Lahun: writing tablets, ready to use, or a board used to teach counting (Szpakowska 2008: 106). We know more from Deir El-Medina, the Theban workmen's village. Many students' exercises on ostraca or writing board, covered with plaster, have survived, some even with the red corrections carried out by the scribe himself or more experienced scribes/teachers (McDowell 2000). One text group, the so-called Miscellanies, clearly describes a teacher-student relationship. Some, mainly on ostraca, seem at times to be in an inexperienced hand, the work of beginners; while the Late Egyptian Miscellanies look as if they have been written in a later stage of education such as an apprenticeship (khery-a). They are longer, mostly well written on papyrus, and sometimes dedicated by a student/assistant to his master. Evidence for further education is also found in colophons on ostraca, stating that this text was copied for a more senior scribe (McDowell 1996). The scribal education started with penmanship (cursive hieroglyphs and hieratic), rather than with the monumental hieroglyphic texts (Williams 1972: 219). These monumental signs were the domain of the draftsman (sesh-kedu) and stonemason; we do not have evidence for their use by scribes in education. However, students learned writing while copying these texts again and again from a master copy or by dictation, starting with complete words, later analyzing the individual inherent signs (Janssen 2007: 66). This was based on the method of memorization: the learners would have known a set of texts by heart, depending on the specific profession to be taken on after their education. There are mistakes in some of the texts, which can be only explained as mnemonic lapses (Brunner 1957: 72). Knowing the right texts showed the students the correct form of letter writing, with all the important formulas as well as the right grammar and orthography. However, if we look at the poor quality of some school texts, we have to admit that grammar did not seem to have the highest priority. The exercises were written on very cheap and readily available ostraca: stone flakes or potsherds. More experienced students used writing boards: small wooden plaster-covered planks, sometimes with a hole in one corner for binding together with the writing equipment (Brunner 1957: 73-4). Expensive papyrus was only used by advanced students for final documents. Rhetoric was always valued, and good examples were given in the chosen manuscripts as instructions, teachings, religious texts, or the classical canon of Egyptian literature, which also supplied the proper moral qualities and ethics. Subjects taught also included mathematics, needed for bookkeeping, and geography, knowledge of which might have been handy for dealing with foreign affairs (Szpakowska 2008: 107). We have no evidence for teaching foreign languages, but at the very least scribes in Amarna must have been able to read and write in cuneiform and presumably must have learned this skill in a formal setting. Students were "encouraged" by punishment (Brunner 1957: 56-9), as it is written in P. Anastasi III 3/13: "the ears of a boy 
are on his back," or as in the above-mentioned Satire on the trades, which makes propaganda for the scribal profession: "I have seen many beatings -/ Set your heart on books!" (Stanza 2; Foster 1999: 121).

A very popular school text in Deir El-Medina was the Kemyt ("the compilation"), which is even quoted in the aforesaid Satire on the trades. These New Kingdom examples of a Middle Egyptian composition, copying a hieratic used at the beginning of the Middle Kingdom, were designed to introduce an apprentice to idioms, forms of writings, letter formulae and word spellings (Wente 1990: 15-17, Williams 1972: 217).

SEE ALSO: Childhood, Egypt; Literacy, Pharaonic Egypt; Literature and poetry, Pharaonic Egypt; Rameses I-XI; Scribes, Egypt; Women, Pharaonic Egypt.

\section{REFERENCES AND SUGGESTED READINGS}

Baines, J. (2007) Visual and written culture in Ancient Egypt. Oxford.

Brewer, D. J. and Teeter, E. (2007) Egypt and the Egyptians. Cambridge.

Brunner, H. (1957) Altägyptische Erziehung. Wiesbaden.

Decker, W. (1975) Quellentexte zu Sport und Körperkultur im alten Ägypten. Sankt Augustin.

Decker, W. (1992) Sports and games of Ancient Egypt. New Haven.

Feucht, E. (1995) Das Kind im Alten Ägypten: die Stellung des Kindes in der Familie und Gesellschaft nach altägyptischen Texten und Darstellungen. Frankfurt.

Foster, J. L. (1999) “Some comments on Khety's instruction for little Pepi on his way to school: Satire on the trades." In E. Teeter and J. A. Larson, eds., Gold of praise: studies on Ancient Egypt in honor of Edward F. Wente: 121-9. Chicago.
Janssen, R. M. (2007) Growing up and getting old in Ancient Egypt: 57-75. London.

Kahl, J. (2007) Ancient Asyut: the first synthesis after 300 years of research. Wiesbaden.

Lichtheim, M. (1976) Ancient Egyptian literature II: the New Kingdom. Berkeley.

Lichtheim, M. (1980) Ancient Egyptian literature III: the Late period. Berkeley.

Manniche, L. (1991) Music and musicians in Ancient Egypt. London.

McDowell, A. (1996) "Student exercises from Deir el-Medina: the dates.” In P. Der Manuelian, ed., Studies in honor of William Kelly Simpson, vol. 2: 601-8. Boston.

McDowell, A. (2000) "Teachers and students at Deir el-Medina.” In R. J. Demaree and A. Egberts, eds., Deir el-Medina in the third millennium $A D$ : 217-33. Leiden.

Morenz, L. D. (1996) Beiträge zur Schriftlichkeitskultur im Mittleren Reich und in der 2. Zwischenzeit. Wiesbaden.

Porter, B. and Moss, R. (1974) Topographical bibliography of Ancient Egyptian hieroglyphic texts, reliefs, and paintings III, 1: Memphis: Abu Rawâsh to Abîsir, 2nd ed. Oxford.

Porter, B. and Moss, R. (1978) Topographical bibliography of Ancient Egyptian hieroglyphic texts, reliefs, and paintings III, 2: Memphis: Saqqâra to Dahshûr, 2nd ed. Oxford.

Roehrig, C. H. (2005) "Senenmut, royal tutor to Princess Nefrure.” In C. H. Roehrig, ed., Hatshepsut: from Queen to Pharaoh: 112-6. New York.

Strouhal, E. and Forman, W. (1992) Life of the Ancient Egyptians: 21-38. London.

Szpakowska, K. (2008) Daily life in Ancient Egypt: 102-21. Oxford.

Toivari-Viitala, J. (2001) Women at Deir el-Medina: a study of the status and roles of the female inhabitants in the workmen's community during the Ramesside period. Leiden.

Wente, E. F. (1990) Letters from Ancient Egypt. Atlanta.

Williams, R. J. (1972) "Scribal training in Ancient Egypt." Journal of the American Oriental Society 92: 214-21. 